\title{
THE CURRENT BATTLES BETWEEN PROGRESSIVE AND CONSERVATIVE MUSLIM WOMEN IN INDONESIA
}

\author{
Nina Nurmila \\ Professor of Gender and Islamic Studies, \\ State Islamic University (UIN) Sunan Gunung Djati Bandung \\ e-mail: ninanurmila@yahoo.com, nina.nurmila@uinsgd.ac.id
}

\begin{abstract}
Perempuan Indonesia telah mampu mengatur diri mereka sejak pra-kemerdekaan. Mereka bersatu untuk meraih kemerdekaan, tetapi mereka juga terbagi berdasarkan agama dan masalah-masalah yang mereka perjuangkan. Dalam masalah poligami, organisasi-organisasi perempuan Kristen dan sekuler cenderung menentangnya, sementara perempuan Islam cenderung setuju menerima poligami sebagai bagian dari syariah Islam yang tidak dapat dilarang. Artikel ini akan membahas tentang perbedaan pendapat antara perempuan muslim progresif dan konservatif, terutama tentang masalah kekerasan seksual, pernikahan anak dan pernikahan poligami. Berbeda dari organisasi perempuan Muslim sebelumnya di tahun 1990an, terdapat peningkatan jumlah perempuan muslim dengan latar belakang pesantren yang lebih berpendidikan dan kritis terhadap interpretasi Alquran yang bias laki-laki. Mereka menentang kekerasan seksual, pernikahan anak dan pernikahan poligami. Namun, ada juga peningkatan jumlah perempuan berpendidikan dengan latar belakang ilmu sekuler dan ilmu sains murni yang cenderung membaca Al-Qur'an secara harfiah dan tidak setuju terhadap diberlakukannya RUU Penghapusan Kekerasan Seksual, mempromosikan pernikahan anak dan pernikahan poligami. Pernikahan poligami dapat disebarluaskan lebih baik di kalangan orang Indonesia dengan menggunakan social media dan fasilitas internet lainnya.
\end{abstract}

Kata Kunci: Progresif, Konservatif, Pernikahan Anak, Poligami, Dan RUU Penghapusan Kekerasan Seksual

\section{INTRODUCTION}

This paper will discuss the current "battles" between progressive and conservative Muslim women, mainly on the issue of sexual violence, child marriage and polygamous marriage. What I mean by progressive thinking of Islam is the one with the strong emphasis on gender equality (Safi, 2003) and tends to interpret the Qur'an contextually; while conservative (or fundamentalist) thinking of Islam is the one with the strong emphasis on the complementary role of men and women, in which men are the leader and the breadwinner of the family, while women are the house wife who serve the husband, take care of the children and do housework (Shehadeh, 2003) and tend to interpret the
Qur'an literally. While progressive Indonesian Muslim women tend to promote Nusantara Islam and avoid Arabization, some conservative Muslim women tend to Arabize themselves such as in the way they speak (adopting terms such as ikhwan, akhwat, ummi), the way they dress and tend to encourage sexual segregation. Interestingly, while some Indonesian conservative Muslims want to Arabize themselves, the Arabs tend to change their Islam into more like moderate 'Nusantara' Islam. This can be seen for example from the statement of the current leader of Saudi Arabia, Muhammad bin Salman (MBS) in the CBS TV station on 19 March 2018 that Arab women do not have to veil themselves. In addition, MBS also allowed women to drive a car and watch 
sport in the stadium (Santi, 2018), even though unfortunately in early November 2019, there was a video circulated in the official twitter of the General Department for Counter Extremism, Saudi Arabia, categorizing feminism as extremism, a punishable crime (Specia, 13 November 2019). This video was criticized and finally being removed on 12 November 2019 and the Saudi Arabia's state security agency asked apology that the video was a mistake (BBC, 13 November 2019).

I will begin the discussion on the "battles" between progressive and conservative Muslim women by providing brief overview of Indonesian discourse of gender and women issues since pre-independence up until now.

\section{DISCUSSION}

\section{The Dynamics of Gender and Women's Issues in Indonesia Since Pre- Independence}

Indonesian women have been active in public sphere far before Indonesian independence. There are well-known Indonesian names who fight physically against the colonial such as Laksamana Malahayati and Cut Nyak Din; and women who fight for women's educational rights such as Kartini and Dewi Sartika (Anwar, 2018). In addition, since the early twentith century, Indonesian women have organized themselves to fight for women's rights, especially to have marriage law which can protect women from child and parentally arranged marriage, arbitrary polygamous marriage and unilateral divorce (Katz and Katz, 1975; Soewondo, 1977; Vreede-de Stuers, 1960 and Wieringa, 1995). The women's organizations' struggles could finally result in the enactment of the 1974 Marriage Law, which sets the minimum age of marriage at 16 for women and at 19 for men, restricts polygamous marriage and divorce (Nurmila, 2009: 54).

The nature of women's organizations themselves vary from time to time. During the colonial era and Soekarno's presidency, there were various religious and secular/nationalist women's organizations who fought for the enactment of the marriage law with different opinion, for example on polygamy. Muslim women's organizations such as Aisyiyah and Muslimat, even though they knew the problematic nature of polygamous marriage in their real life, they supported their male organizations (Muhammadiyah and Nahdlatul Ulama) in opposing the prohibition of polygamous marriage (Wieringa, 1995: 141) proposed by Christian and secular/nationalist women's organization (Locher-Scholten, 2003: 51). During Soekarno period (1945-1965), women's organizations also tended to be divided into Muslim religious organizations such as Aisyiyah and Muslimat; the nationalist organizations such as Kowani and leftist organization such as Istri Sedar which then became Gerakan Wanita Indonesia (Gerwani). Gerwani was one of the progressive women's organizations which worked in the grass root level educating women farmer how to read and to organize themselves (Wieringa, 1995), which show their support for women's public roles. They also paid attention to the wifely and motherly duties such as cooking, sewing, rearing children and keeping the house hygiene (see Gerwani's magazine, Api Kartini, 1960; 1961; and QBUKATABU, 2017). However, Gerwani was disbanded in 1965 and even stigmatized by the New Order government as the dangerous communist women's organization (Wieringa, 1995). The New Order government formed new women's organization, called Dharma Wanita (Women's Virtue) which emphasizes women's domestic roles as wife who should serve her husband and as mother who take care of her children and do the housework. This is what Julia Suryakusuma (2004) calls state ibuism, in which women's subordinate and domestic roles were constructed and idealized throughout the New Order period (1966-1998). 
Nevertheless, within this authoritarian regime of the New Order, institutions which support women's rights and argue against the existing mainstream gender construction were also established. For example, Kalyanamitra was established in 1985 with the aim of establishing a democratic civil society and gender justice through the advancement of women's movement in Indonesia (Anwar, 2018); Perhimpunan Pengembangan Pesantren dan Masyarakat/ P3M (Association for Pesantren and Society Development), which was established 1983, also has fiqhunnisa (Muslim understanding of women's issues) program in the early 1990s which aimed at educating pesantren (Islamic Boarding School) women on their reproductive rights; Fatayat, the young women's wing of Nahdlatul Ulama/NU, developed Yayasan Kesejahteraan Fatayat in 1990 and offered intensive training for pesantren leaders (kiayis/nyais) on reproductive health, which include the discussion on gender issues in Islam (Srimulyani, 2012: 60). The discussion on gender in Islam had been increasingly more flourishing since the early 1990s with the translation of the articles and books by Muslim feminists such as Riffat Hassan, Fatima Mernissi, Amina Wadud and Ashgar Ali Engineer into Indonesian language (Nurmila, 2011).

After the New Order era ended in 1998, several non-government organizations with progressive interpretations on gender discourse in Islam such as Puan Amal Hayati (which focuses on rereading Muslim classical texts from equal gender perspective), Rahima (which gives information on women's reproductive rights in Islam) and Fahmina (which deals with democracy, pluralism and gender justice) were founded by NU based activists in 2000. The peak period of the progressive discourse of Islam was in 2001, under the presidency of Abdurrahman Wahid (Gus Dur), who is also one of the well-known figures of progressive Muslim.
It was under his presidency also that the name of the Ministry of Women's Role changed into the Ministry of Women Empowerment and Children Protection whose minister was Khofifah Indar Parawansa, an NU woman's activist.

After 2001, there seems to be gradual backlash into conservative discourse of Islam, which of course affected the discourse of gender and women's issues in Islam. The tragedy of September 11, 2001 in New York (which is famous with 9/11) had caused Islamophobia and in response to it, there has been resurgence of conservative and radical Islam. Van Bruinessen calls the phenomenon of this conservative resurgence as the "conservative turn" which he noticed to happen in Indonesia by 2005 (2013: 3). In Indonesia, the resurgence of conservative and radical Islam can be seen, for example, in the production of discriminative policies by some local governments and MUI fatwa against religious minority groups such as Ahmadiyah and Syiah. Some of the impacts of these policies were the increasing number of violence against Ahmadiyah and Syiah followers and the seal of their mosque. Some of them have become internally displaced people who have to live in evacuation camp with very limited facilities which endanger women's reproductive health (Komnas Perempuan, n.d. a; Komnas Perempuan, n.d. b). Some local governments such as in Aceh, Sumatra Barat, Bengkulu, Jawa Barat, Jawa Timur and Yogyakarta also issued curfew, obligation for women to veil and regulation prohibiting prostitution (Husna, 2015; Siddiq, 2018). These regulations disadvantage women resulting in the assumption that women who go out at night are prostitutes, while in fact some women such as doctors, nurses, factory workers often have a night shift and not all of them have the luxury of going to/back from work by using private car. The late Ibu Lilis, one of the restaurant workers in Tangerang was mistakenly arrested by the local security in 
Tangerang while she was waiting for public transport in the street at night because she was being assumed to be prostitute. This arrest has created stigma and led her to be sacked by her employer and being isolated by her neighbors. Her husband was also fired from being a teacher because of the stigma of having prostitute wife. Due to both of their unemployment, they have huge debt. The stress she experienced caused her to have miscarriage and she finally died (Komnas Perempuan, 2010). The above cases show the danger of discriminative policies on women issued by conservative local government.

\section{The "Battles" between Progressive and Conservative Muslim Women in Indonesia}

In the above context of the increasing influence of conservatism, Kiayi Husein Muhammad, pesantren leader of Darut Tauhid Arjawinangun, Cirebon, who was also one of the founders of Fahmina and Rahima, founded Alimat in 2009. Alimat is a movement for equality and justice in Indonesian Muslim family. Even though Alimat literally means women's scholars/ulama, its members include men with gender justice perspective. Alimat differentiate between female ulama and women ulama: female ulama are the ulama who are biologically female, while women ulama are scholars, either male or female, who have gender justice perspective. The name of Alimat itself challenges male dominance in Islamic scholarship and claims that women are fully human beings who are capable of producing knowledge. Alimat is like an umbrella for many women's organizations whose members are open to women from Aisyiyah, Fatayat, Muslimat, and academicians who mainly have pesantren educational background, including myself. Alimat is also part of Musawah, a global movement for equality and justice in the Muslim family. One of Musawah leaders, Zainah Anwar from Sisters in Islam Malaysia, is very passionate about the progressive thinking of Alimat and therefore she often invites Alimat executive board, especially Nur Rofiah and Faqihuddin Abdul Kodir, to give gender and Islam training in Malaysia to counter conservatism.

In April 24-27, 2017, Alimat together with Rahima and Fahmina organized the first Indonesian congress of ulama, Kongres Ulama Perempuan Indonesia (KUPI), attended by about thousand participants who consist of women ulama, women leaders of pesantren, women activists, academicians throughout Indonesia as well as guest speakers and observers from thirteen other countries namely America, Australia, Netherlands, Malaysia, Thailand, Singapore, the Philippines, Saudi Arabia, Pakistan, India, Nigeria, Kenya and Bangladesh. In this congress, in supporting the Elimination of Sexual Violence Bill, KUPI issued three fatwa (religious opinion) on sexual violence, child marriage and environmental issues (Tim KUPI 2017). On sexual violence KUPI argue that: (1) all forms of sexual violence are prohibited (haram), within and outside marriage; (2) Rape is different from zina, on their definition, punishment and verification, even though both have similarities that zina and rape can have long term effect on women's reproduction such as pregnancy, giving birth and taking care of the baby; (3) the state is responsible for the safety of the citizens, therefore, law enforcement officials who do not do their jobs and even become the perpetrators of sexual violence should be punished heavier than the general perpetrators. On child marriage, KUPI argue that (1) preventing child marriage in order to create happy and peaceful family is obligatory because child marriage give more disadvantages than advantages; (2) parents, society, government and the state are responsible for preventing child marriage; (3) what can be done to victims of child marriage as a form of protection is to ensure the children's rights are fulfilled as any other children especially their right for education, health, parents' guardianship and 
protection from all forms of violence, exploitation and discrimination. On environmental destruction, KUPI issued religious opinion that: (1) destructing the environment which endanger and cause social injustice for any reasons including development is prohibited (haram) because this universe is created by Allah not to be destroyed but to be conserved; (2) religion should play the role in protecting the environment; (3) the state is obliged to protect the environment from any destruction and have to punish those who destruct the environment, either the individual, the society, the state officials and especially the corporation (Tim KUPI 2017, pp. 86-91, 116-8, 142-5). On polygamy, most Alimat members argue against polygamy because this type of marriage is closer to injustice against women. This opposition to polygamy can be seen for example in the works of Kiayi Husein Muhammad, one of the former commissioners of Komnas Perempuan, who argues that Islam has gradually reformed the marriage from unlimited into limited to four and then one. According to him, Muslims should have been monogamous since centuries ago (2011). In addition, Abdul Kodir's standpoint about polygamous marriage can be clearly seen in his book that monogamous marriage is preferable (2005). To sum up, progressive Muslims argue against sexual violence within and outside marriage; child marriage, environmental destruction and polygamous marriage.

In contrast, conservative group such as Aliansi Cinta Keluarga (Aila) and Penggiat Keluarga (Giga) question about sexual violence within marriage. In her lecture at Universitas Pendidikan Indonesia (UPI) on 15 February 2019 which I attended, Euis Sunarti, Aila leader, in opposition to the enactment of the Elimination of Sexual Violence Bill, argued against the report of violence made by the wife against her husband. For the sake of family resilience, in her opinion, it is better for the wife not to report her husband's violence because the husband is the imam (the leader) of the family and reporting her husband's violence will make the family falls apart.

In contrast, in the Reform Era (after 1998), conservative group also tend to promote child marriage and polygamy. For them, it is better to marry off girls early rather than committing zina (Adhim, 2002). More recently, this conservative group posted the campaign "Indonesia tanpa pacaran" [Indonesia without dating] in the social media such as Instagram, Facebook and Line beginning September 2015. However, lately, this conservative movement is not only online but also grounded in their action against dating. For example, this group sweep a dating couple in Depok, West Java, by approaching the dating couple in group, advising and even offering them to facilitate their marriage right away unregistered. This, according to Reni Sumarso, one of the lecturers of Universitas Indonesia, is worrying and may lead to social conflict if this sweeping is not being stopped (Gunadha, 20 April 2019). Many of the conservative also believe that polygamous marriage is permitted in Islamic sharia. The promotion of polygamy has been up and down since 2000 for example by the restaurateur Puspo Wardoyo who had four wives and gave award to those who practiced it in 2003 (Nurmila, 2005, 2017). There have also been online campaign for polygamy by creating Google Playstore ayopoligami.com in April 2017. However, this application has been mainly used to have dirty chat (Ratnasari, 26 September 2017). The owner of this application, Lindu Cipta Pranayama, who found her wife through this application, decided to delete 56,000 users who have misused this application for dirty chat and this application could no longer be accessed since September 2017. Pranayama felt afraid of being sinful for facilitating dirty chat (Kumparan TECH, 12 September 2017).

Recently, there has been a hot debate about the proposed draft of Aceh Muslim family law (Rancangan Qanun Hukum 
Keluarga, 2019; Tempo, 18 July 2019), which includes the regulation on polygamy similar with that of in the Indonesian Compilation of Islamic Law (Kompilasi Hukum Islam) and the 1974 Marriage Law (Undang-Undang Perkawinan No. 1/1974). The different is that this draft tend to make the practice of polygamy easier by proposing that the requirements for polygamy is alternative, not cumulative like in the Marriage Law and the Compilation. In addition, unlike in the Marriage Law and the Compilation, the Religious Court (Mahkamah Syar iyah) can give the husband permission to practice polygamous marriage, even when the existing wife/wives are unwilling to give the permission. Not only about polygamy, Aceh which tends to read Islam literally, has issued many other regulations which disadvantage women such as the prohibition for women to straddle in the motorcycle, to work and go out at night and to play football (Setyadi, 5 July 2019).

In opposing progressive group who claim themselves to be Muslim feminist and in opposing the Elimination of Sexual Violence Bill, some conservative group argue against feminism by posting their disagreement to feminism in their Instagram: "\#Indonesia tanpa feminis!!" and "\#uninstall feminism" in March 2019 (Mazrieva, 2019).

\section{CONCLUSION}

Unlike what happened during preindependence up until the New Order period, when religious and secular organizations were in conflict on the issue of polygamy, after the reform era, progressive Muslim feminists and secular feminists support each other in their struggle for the enactment of the Elimination of Sexual Violence Bill and in facing the opposition from the conservative Islamist group such as Aila, Giga, and Indonesian anti-feminist movement. The raising influence of conservatism, indeed affect the fulfilment of women's human rights such as their rights to choose how to dress, to mobilize themselves and to free themselves from child marriage, sexual violence and unjust polygamous marriage. Both groups: the conservatives and the progressives continue their "battle" in attracting public support for their ideas, online and offline. These battles can be seen from their promotion of child marriage, polygamy and their opposition to the Elimination of Sexual Violence Bill by the conservatives on one side, and the support for Elimination of Sexual Violence Bill and opposition to child marriage and polygamy by the progressive Muslim feminists on the other side. Recently, Aisyiyah of Muhammadiyah, even declared that the door for polygamy has been closed (Yusuf, 19 November 2019), showing their clear opposition to polygamy, which has been declared to be haram, by Muhammad Abduh (1849-1905) (Rida, 1973: 350), Egyptian Muslim reformist whose reformism became the basis for the foundation of Muhammadiyah in Indonesia in 1912. This current clear opposition of Aisyiyah to polygamy was different from early Aisyiyah members who tended to be "more accommodative" to male biased "support" for polygamy. This, according to my opinion, is because there has been increasing number of Aisyiyah members and leaders who have been more educated and therefore have been more critical and brave enough to challenge male biased interpretation of the Qur'an which disadvantage women.

\section{REFERENCES}

Abdul Kodir, Faqihuddin (2005). Memilih monogami: pembacaan atas AlQur'an dan hadits Nabi. Yogyakarta: Pustaka Pesantren.

Adhim, Muhammad Fauzil (2002). Indahnya Pernikahan Dini. Dadi M Hasan Basri (ed.). Jakarta: Gema Insani Press. 
The Current Battles Between Progressive and Conservative Muslim Women in Indonesia $\| 7$

Anwar, Etin (2018). A Genealogy of Islamic Feminism: Pattern and Change in Indonesia. London and New York: Routledge.

BBC (13 November 2019). "Saudi Arabia apologises for video labelling feminism as extremism", https://www.bbc.com/news/worldmiddle-east-50401311, accessed 24 November 2019.

Gerwani (1960). Api Kartini. Jakarta: Gerwani.

Gerwani (1961). Api Kartini. Jakarta: Gerwani.

Gubernur Aceh (2019). "Rancangan Qanun Hukum Keluarga (Ahwal alSyakhshiyah). Circulated but unpublished draft.

Gunadha, Reza (2019). "Sering Sweeping, Gerakan Indonesia Tanpa Pacaran Resahkan Warga Depok", https://www.suara.com/news/2019/04 /20/213307/sering-sweepinggerakan-indonesia-tanpa-pacaranresahkan-warga-depok, accessed 21 July 2019.

Kalyanamitra (2019). "Kalyanamitra. Pusat Komunikasi dan Informasi Perempuan", http://jaringanaksiremaja.com/jaringa n/kalyanamitra/, accessed 19 July 2019.

Katz, June S. and Katz, Ronald S. (1975). "The new Indonesian Marriage Law: A mirror of Indonesia's political, cultural, and legal systems", American Journal of Comparative Law 23, 4: 653-81.

Komnas Perempuan (n.d.a). Atas Nama (VCD). Jakarta: Komnas Perempuan.

Komnas Perempuan (2010). Advokasi Kebebasan Beragama Jemaat Ahmadiyah di Nusa Tenggara Barat. Jakarta: Komnas Perempuan.
Komnas Perempuan (n.d.b). Laporan Tim Temuan dan Rekomendasi (TTR) tentang Penyerangan terhadap Penganut Syiah di Sampang Madura (VCD). Jakarta: Komnas Perempuan.

Kumparan TECH (12 September 2017). "Founder AyoPoligami Nikahi Pengguna Aplikasinya", https://kumparan.com/@kumparantec h/founder-ayopoligami-nikahipengguna-aplikasinya, accessed 19 July 2019.

Mazrieva, Eva (2019). “'Indonesia Tanpa Feminis,' Kritik atau Bunga Tidur?", https://www.voaindonesia.com/a/indo nesia-tanpa-feminis-kritik-ataubunga-tidur-/4858116.html, accessed 21 July 2019.

Muhammad, Husein (2011). Ijtihad Kyai Husein. Upaya membangun keadilan gender. Rahima: Jakarta.

Nisa, Eva F (2019). "Muslim Women in Contemporary Indonesia: Online Conflicting Narratives behind the Women Ulama Congress", Asian Studies Review, https://doi.org/10.1080/10357823.20 19.1632796

Nurmila, Nina (2005). "Polygamy and Chickens," Inside Indonesia, JulySeptember.

Nurmila, Nina (2009). Women, Islam and Everyday Life. Renegotiating polygamy in Indonesia. London: Routledge.

Nurmila, Nina (2011). "The Influence of Muslim Global Feminism on Indonesian Muslim Feminist Discourse," Al-Jami `ah, UIN Yogyakarta, Vol. 49, No. 1, pp.33-64.

Nurmila, Nina (2017). "No popular support for polygamy. Time for Indonesia to ban the practice," Policy Forum, 29 November 2017, https://www.policyforum.net/no- 
popular-support-polygamy/, accessed 22 July 2019.

QBUKATABU (2017). “Gerwani: Ibu Militan, Api Kartini \& Ingatan ttg Kampanye Hitam terhadap Gerakan Perempuan", https://qbukatabu.org/2017/09/30/ger wani-ibu-militan-api-kartini-ingatanttg-kampanye-hitam-terhadapgerakan-perempuan/, accessed 15 July 2019.

Ratnasari, Elise Dewi (2017). "Pengakuan Seorang Pengguna Situs Poligami: Saya Jijik", https://www.cnnindonesia.com/gayahidup/20170926142407-282-

244116/pengakuan-seorang-

pengguna-situs-poligami-saya-jijik, accessed 21 July 2019.

Rida, Muhammad Rashid (1973). Tafsīr alQurān al-h .akīm: Al-shahīr bi-tafsīr al-Manār, Vol. 4 (ed.), Beirut: Darul Ma'rifah.

Safi, Omid (2003). Progressive Muslims: On Justice, Gender, and Pluralism. London, England: Oneworld.

Santi, Natalia (2018). "Putra Mahkota Saudi Sebut Wanita Tak Perlu Pakai Kerudung", https://www.cnnindonesia.com/intern asional/20180321181755-120284810/putra-mahkota-saudi-sebutwanita-tak-perlu-pakai-kerudung, accessed 20 July 2019.

Setyadi, Agus (5 July 2019). “Tolak Liga Sepakbola Putri, Ulama Aceh: Main Bola untuk Perempuan Haram", https://news.detik.com/berita/d4612892/tolak-liga-sepakbola-putriulama-aceh-main-bola-untukperempuan-haram, accessed 22 July 2019.

Shehadeh, Lamia Rustum (2003). The idea of women in fundamentalist
Islam. Gainesville, FL: University Press of Florida.

Siddiq, Taufiq (2018). "Daerah dengan Perda Syariah dan Injil dari Aceh hingga Papua”, https://nasional.tempo.co/read/11474 30/daerah-dengan-perda-syariah-daninjil-dari-aceh-hingga-papua, accessed 21 July 2019.

Soewondo, Nani (1977). "The Indonesian Marriage Law and its implementing Regulation”, Archipel 13: 283-94.

Specia, Megan (2019). "Saudi AntiExtremist Force Names Feminists as a Target. Briefly", https://www.nytimes.com/2019/11/13 /world/middleeast/saudi-feminismextremism-video.html, 13 November 2019, accessed 24 November 2019.

Srimulyani, Eka (2012). Women from Traditional Islamic Educational Institutions in Indonesia. Amsterdam: Amsterdam University Press.

Suryakusuma, Julia I. (2004). Sex, Power and Nation. Jakarta: Metafor Publishing.

Tempo (18 July 2019). "Kontroversi Aturan Poligami Aceh", https://kolom.tempo.co/read/1224559 /kontroversi-aturan-poligamiaceh/full\&view=ok, accessed 22 July 2019.

Tim KUPI (2017). Tim KUPI, Dokumen Resmi Proses\&Hasil Kongres Ulama Perempuan Indonesia. Cirebon: Kongres Ulama Perempuan Indonesia.

van Bruinessen, M. (2013). "Introduction: Contemporary developments in Indonesian Islam and the 'conservative turn' of the early twenty-first century". In $M$. van Bruinessen (Ed.), Contemporary developments in Indonesian Islam: Explaining the "conservative turn" 
The Current Battles Between Progressive and Conservative Muslim Women in Indonesia $\| 9$

(pp. 1-20). Singapore: Institute of Southeast Asian Studies.

Vreede-de Stuers, Cora (1960). The Indonesian Woman: Struggles and Achievements. The Netherlands: Mouton.

Yusuf, Nurbani (19 November 2019) “ Tanwir 'Aisyiyah: Melawan Fikih Maskulin, Menutup Pintu Poligami”, https://ibtimes.id/tanwir-aisyiyah- melawan-fikih-maskulin-menutuppintu-poligami/, accessed 24 November 2019.

Wieringa, Saskia (1995). "The politicization of gender relations in Indonesia: the Indonesian women's movement and Gerwani until the New Order state", unpublished PhD thesis, the University of Amsterdam. 